and the barred owl also decreased. Marsh hawk and the red-shouldered hawk populations have not changed appreciably. The bald eagle has been increasing in numbers since the early 1940 's; but this is the only species for which a notable increase was shown. The records for many species are too incomplete to evaluate.

Because the decline in raptor populations is shown particularly among the less-wary species and those species that are most likely to be encountered by man, it is suggested that man may be directly responsible for the decline. This view is corroborated by the fact that many raptor band returns are from birds that were trapped or shot and also by the indication that a notably lethargic species, the rough-legged hawk, has suffered the severest decline.

The species of raptors, namely, Buteo spp., Circus spp. and Falco sparverius, which have been protected by law since 1919, were seen at least seven times as frequently as the previously unprotected accipiters and the great horned owl.

\title{
SINGAPORE BOTANIC GARDENS
}

\begin{abstract}
A
SPECIAL issue of the Gardens' Bulletin (17, Pt. $2 ; 1959$. 12.50 dollars. Obtainable from the Botanic Gardens, Singapore) has been issued to commemorate the hundredth anniversary of the founding of these well-known gardens. In fact, a botanic garden was established in Singapore soon after its founding in 1819 by Sir Stamford Raffles, nutmegs, cloves and cocoa being among the early introductions. This garden was closed after some years in a retrench ment of expenditure, but new gardens, the present ones, were established on a new 60-acre site towards the end of 1859 (see also Nature, 184, 1602; 1959).

Since then the gardens have been extended and amplified and for many years have been recognized as being among the most important tropical institutions of this kind, the more so as they are set in a region of very considerable agricultural importance and quite exceptional floristic interest. Virtually from the outset, the staff have paid attention to the needs of practical agriculture and horticulture as well as to systematic and other aspects of scientific botany usually associated with botanic gardens. This was exemplified in a remarkable degree by the work of Dr. H. N. Ridley, director of the Gardens during 1888-1912, who has not only been rightly named "the father of Malaya's rubber industry" but was also responsible, as an indefatigable field botanist, for vast accessions of new plants to the gardens and its horbarium. After his retirement, he produced his
\end{abstract}

five-volume work on the "Flora of the Malay Peninsula" (1922-25).

As several distinguished botanists have worked on the staff of the Singapore Botanic Gardens over the years, the output of work, often on plants of unusual scientific interest, has been both extensive and impressive. In the present commemorative volume (pp. 125-340) the reader will find much that is pertinent, informative and interesting. J. W. Purseglove has contributed a paper on the history, functions and contemporary work of the gardens; T. A. Russell has described the relationships between them and the Royal Botanic Gardens, Kew ; while H. J. Lam has written of Singapore and Leyden. Other authors deal with the contribution which work in the gardens has made to agriculture in the Malaysian region, and there are several papers of both general and special interest by well-known botanists ; for example, R. E. Holttum has written on his work on orchids, gingers and bamboos carried out in the gardens, and E. J. H. Corner has discussed the importance of the taxonomy of tropical plants in contemporary botany; and so on.

Perhaps the best way of indicating briefly the value of the present volume is simply to say that, for the general botanical reader, it affords an unusually interesting introduction to the many facets and fascinations of tropical botany.

\section{ROAD ACCIDENTS DURING CHRISTMAS 1959}

$\mathrm{T}$ WO factors stand out in the Road Research Laboratory report of the investigation of the 150 fatal road accidents in England and Wales during the Christmas period (December 24-27, 1959)--the bad weather conditions and the unusually high proportion of people involved in the accidents who had taken alcohol (Road Research Technical Paper. No. 49. Pp. iv +20 . Published for the Department of Scientific and Industrial Research by H.M. Stationery Office, 1960. 1s. 9d. net).

The investigation was carried out at the request of the Minister of Transport and shows that the number of fatalities per mile travelled by motorvehicles was high on each of the four days of the Christmas period when compared with the other days in December or with the year as a whole.

The factors usually associated with road accidents (such as vehicle defects, cross-roads, and skidding on wet roads) were present in the normal proportion.
The weather conditions were bad. Roads were dry for only 10 per cent of the accidents; in 73 per cent it was dark and wet; in 12 per cent it was daylight and wet; and in 5 per cent it was icy. The report states: "this weather would be expected to result in increased accident frequency but not to the extent that occurred".

In at least 56 per cent of the accidents one or more of the people involved had taken alcohol not long before the accident. The corresponding figure in a normal period is 18 per cent. The report concludes : "the bad weather of the Christmas period made travelling conditions difficult. The fact that many of the people involved in the accidents had been drinking beverages containing alcohol would be expected--in the light of previous research-to have made many of them less able than usual to deal adequately with the difficult conditions. Although other factors may have been involved, the combination of these two alonemight account for the high accident-rate over the period". 